\title{
IMPACT OF CULTURAL DIFFERENCES ON LOYALTY PERCEPTION
}

\author{
Andrea KRÁLIKOVÁ; Patrik KUBÁT; Kateřina RYGLOVÁ \\ Mendel University in Brno, Faculty of Business and Economics, Department of Marketing and \\ Trade, Brno, the Czech Republic
}

\begin{abstract}
Purpose: The key objective of this study is to investigate whether the cultural and geographical differences are significant within the context of destination loyalty.

Design/methodology/approach: The perception of the Czech Republic as a tourist destination as well as the impact of American, Russian and Finnish nationalities on tourist loyalty towards the Czech Republic were examined. Multiple regression analysis (OLS method) was used in order to evaluate the impact of particular image factors on loyalty indicators and the Kruskal-Wallis test was used to evaluate the dependence of image factors on the respondents' personal characteristics.

Findings: Cultural monuments played the biggest role for the American and Finnish respondents. On the other hand, safety and food quality were the most important factors for the Russian respondents. Regardless of the nationality, there are four high-priority factors - cultural and natural attractions, safety, and acceptance by the locals. The closer attention should be therefore paid to factors of safety and acceptance by the locals, as they can be to some extent, altered by the government.

Research limitations: The data were obtained before the COVID-19 pandemic. Consequently, the Czech Republic perception might differ from the pre-COVID-19 era. Practical implications: The results of this paper can be used by various service providers in central European countries, that are mostly oriented on cultural and city tourism, for their marketing and management plans as well as campaigns. Service providers can also use these results to better target their visitors and their offerings to them.
\end{abstract}

Key words: cultural differences, destination image, loyalty, the Czech Republic. JEL classification: Z30, M14, L83.

\section{Introduction}

As a result of pandemic restrictions, there is a substantial decrease in the number of tourists, both on domestic as well as international level. Therefore, the loyal visitors might be seen as a huge benefit for various service providers and destinations in the post-COVID-19 era. Not only does loyalty help to reduce marketing costs that can be used to ensure several health and safety requirements regarding COVID-19 (Zhang et al. 2014), loyal visitors are also inclined to stay longer at the destination (Lau, McKercher 2004).

However, to ensure visitors' loyalty is not an easy task, as there is a great number of factors that have an impact on loyalty, e.g. visitors' satisfaction (Forgas-Coll et al. 2012), destination image (Chi, Qu 2008), perceived value (Chi 2012), uniqueness of destination (Usakli, Baloglu 2011), political stability and safety (Loi et al. 2017), visitors' personality (Skogland, Siguaw 2004) and even the cultural differences (Chen, Gursoy 2001).

https://doi.org/10.11118/978-80-7509-820-7-0397

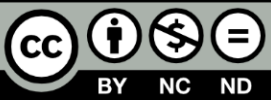


Cultural differences are not only influencing the visitors' loyalty, they might also lead to different perceptions of destination and their tourism services and can therefore influence the destination image formation and perception (Chen, Tsai 2007). Hence, the purpose of this study is to evaluate the impact of cultural and geographical differences on the destination loyalty perception.

\section{Literature review}

In the tourism sector, loyal visitors are highly desirable and perceived as a competitive advantage among other destinations and service providers (Sun, $\mathrm{Chi}, \mathrm{Xu}$ 2013). Therefore, loyalty has become one of the most researched topics in the tourism industry. For instance, Hultman et al. (2015) define visitors' loyalty as a degree of attachment to a particular destination. On the other hand, some authors, like Su, Cheng, Huang (2011), identify destination loyalty from a psychological perspective, as a complex socio-psychological structure that is influencing tourist behavior and emotions.

Accordingly, tourist loyalty, behavior and emotions are influenced by various psychological and demographic factors, such as motivation, lifestyle and visitors' personality (Beerli, Martin 2004). All of these factors are to some extent influenced by the culture that visitors come from. Moreover, culture has an impact on visitors' values and behavior (Govers, Go, Kumar 2007) as well as destination image perception (Bonn, Joseph, Dai 2005). Therefore, according to Lopes (2011), the country of origin is the most important demographic factor.

Moreover, demographic factors such as age, travel distance or even the country of origin has an impact on tourists' revisit intention (Štumpf, Vojtko, Janeček 2020), travel motivation (Swarbrooke, Horner 2007), destination choice and tourist behavior (Jackman et al. 2020).

On that account, it can be assumed that image and loyalty perception might significantly differ with regard to cultural and geographical differences. It is therefore inevitable to evaluate this assumption as it might provide useful insights into the destination loyalty formation.

\section{Methodology}

The key objective of this study is to investigate whether the cultural and geographical differences are significant within the context of destination loyalty. In order to achieve this objective, the primary data among American, Finnish and Russian respondents were collected. The data were obtained via an online questionnaire and structured interviews during 2017 and 2019.

The detailed sample structure is presented in Figure 1. Unfortunately, we were not able to apply quota sampling based on gender in the case of Russian respondents.

Based on Chen, Tsai (2007) we used two loyalty indicators, intention to revisit the Czech Republic sometime in the future and intention to recommend the Czech Republic to friends and family. In addition, the researched image factors were 
formulated based on previous studies (Nunkoo 2013; Zhang 2013; Wu 2016; Ryglová et al. 2018; Viet 2019).

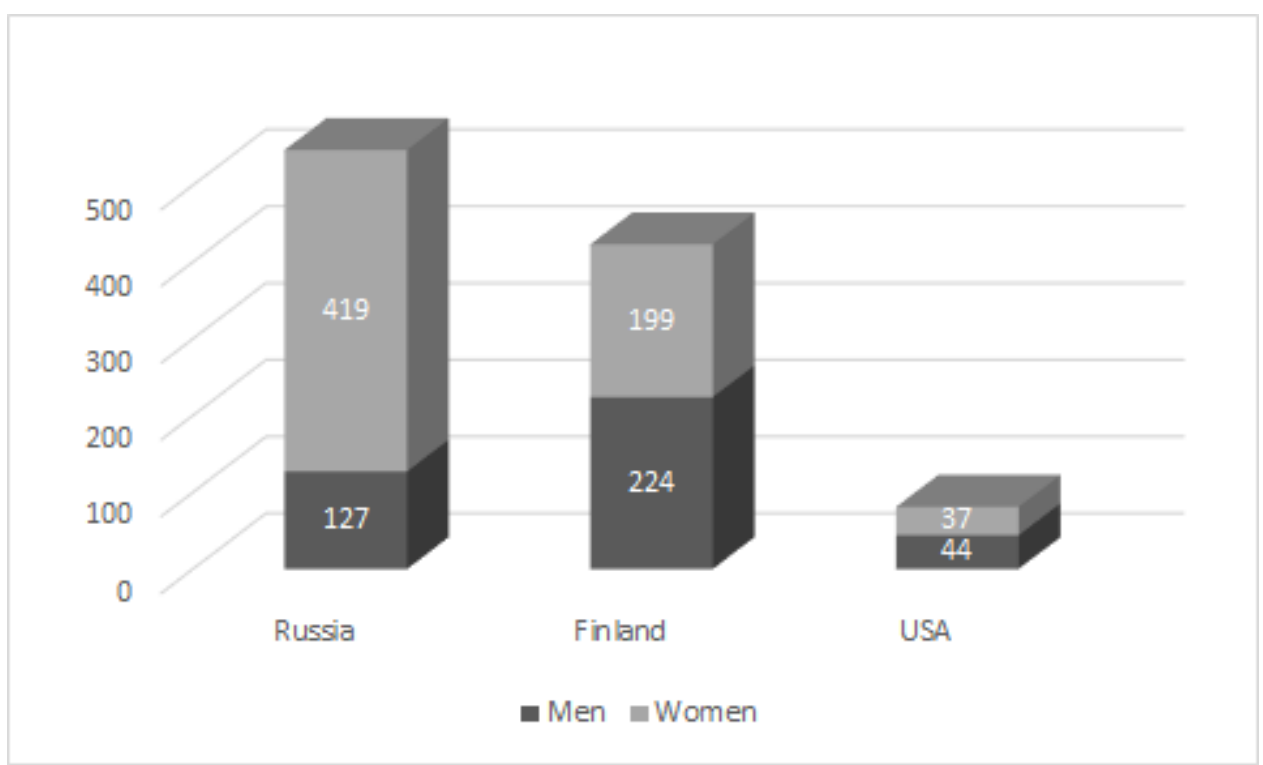

\section{Figure 1. Sample Structure}

Source: Own Processing

To assess the impact of image factors on the two loyalty indicators, a multiple regression analysis using the OLS method was used. Furthermore, Kruskal-Wallis test was used to evaluate the dependence of image factors on the respondents' characteristics, like age or gender.

\section{Results and discussion}

As it was mentioned in the literature review, tourist loyalty is one of the most crucial issues in tourism regarding the post-COVID-19 era. It is therefore inevitable to know whether the cultural as well as geographical differences have an impact on tourist loyalty perception.

If we look at Figure 2 we can see that the different nationalities evaluate the particular loyalty indicators differently. Compared to Russian and Finnish respondents, the least loyal to the Czech Republic were American respondents. Only about $57 \%$ of those Americans who already visited the Czech Republic would come back in the future. Looking at the recommendation, almost $63 \%$ of American respondents would recommend the Czech Republic to their friends and family.

This might be the result of the great geographical difference between the Czech Republic and the US (compared to Russia and Finland, the United States are farthest from the Czech Republic). However, roughly $75 \%$ of American respondents were satisfied with their stay in the Czech Republic, which is a very favorable situation for service providers. 


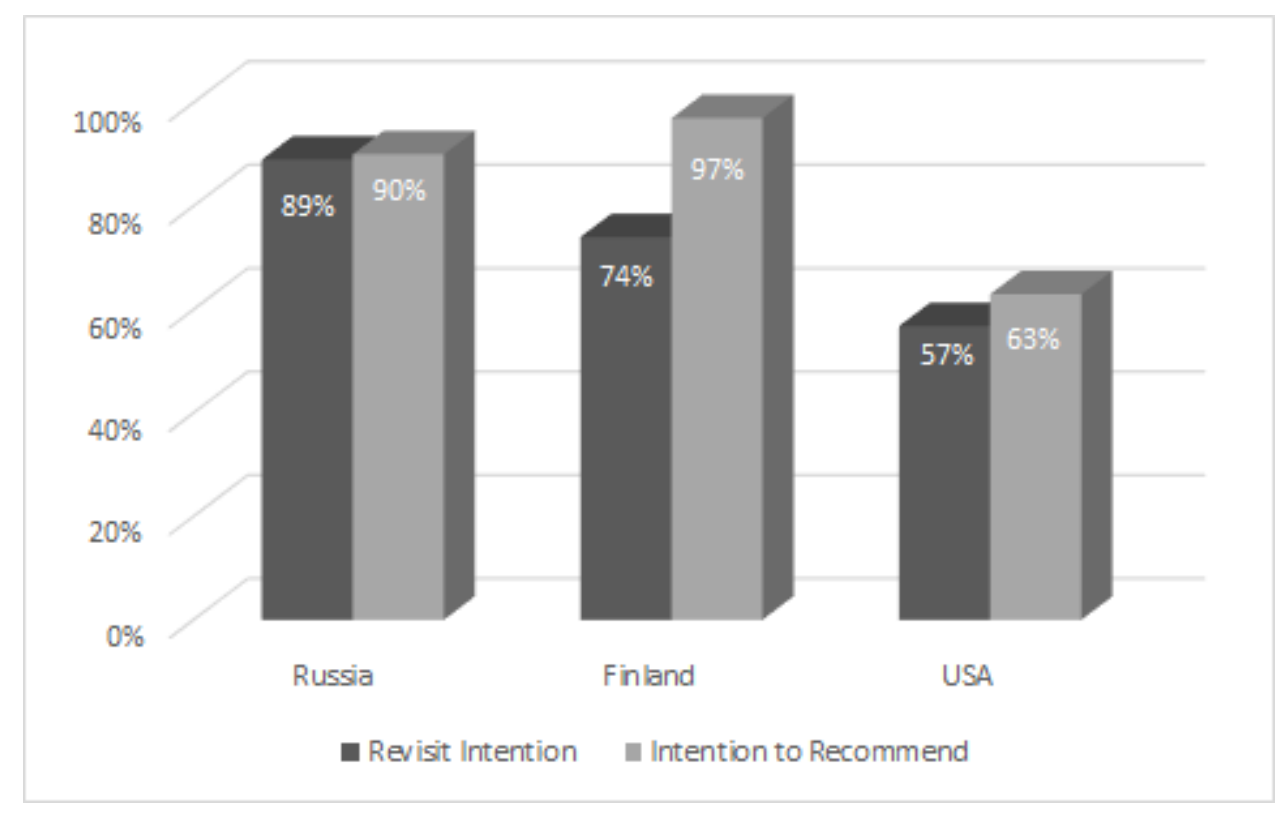

Figure 2. Loyalty Indicators

Source: Own Processing

On the other hand, the most loyal to the Czech Republic, among other researched nationalities, are Russians. This is also evident from the analysis of CzechTourism, where the main information sources for Russian visitors were recommendations from friends and family, as well as travel agencies, the internet, and their own experience (Country Report Russia 2020).

Furthermore, the results of our research indicate that more than $61 \%$ of the Russian respondents received their information regarding the Czech Republic from their acquaintances, followed by the internet (almost $43 \%$ ) as well as the social media (approximately $18 \%$ ).

Same goes for the Finnish respondents, where their own experience (nearly $69 \%$ ) has the largest influence on their destination selection process, closely followed by their friends and family (more than $60 \%$ ), as well as the social media (approximately $29 \%)$.

Moreover, the intention to recommend is stronger than the intention to revisit the Czech Republic. This is especially evident in the case of Finnish respondents. That might be caused by the fact that some tourists are visiting particular destinations to experience something new. Nevertheless, further research is needed to confirm this claim. On the other hand, according to Gursoy, Chen, Chi (2014), the intention to revisit a certain destination is rather small, because of this reason. Furthermore, the referrals are considered as a valuable source of information, especially in the tourism sector (Beerli, Martin 2004). 
If we look closely at the various image factors based on the respondents' nationality, we can see substantial differences in their evaluation. Americans evaluated the cultural monuments the highest. Furthermore, they perceive the historical monuments of Prague as the unique attractions of the Czech Republic. In a similar manner, Finnish respondents evaluated the cultural monuments the highest as well. Contrary to Americans, they also rank the perception of the Czech Republic as a beer country very high. On the other hand, safety and food quality were the most important factors for Russian respondents. They also evaluated price category factors higher compared to other researched nationalities.

Regardless of the respondents' nationality, there were four high-priority factors that play a crucial role in loyalty perception. Those factors are cultural and natural attractions, safety, and acceptance by the locals. The closer attention should be therefore paid to factors, safety and acceptance by the locals, as they can, to some extent, be altered by the service providers or policy makers. Moreover, the perception of a safe country is very crucial, especially during the COVID-19 restrictions. Hence, it should be the main focus of every Czech DMO (Destination Management Organization).

Nevertheless, the results of Kruskal-Wallis test confirm the dependence of image factors on gender of respondents. In case of American and Finnish respondents, men evaluated researched image factors higher than women. Contrastingly, Russian women evaluated these factors higher than men. However, this might be the result of the low number of men among Russian respondents. Moreover, the KruskalWallis test confirmed the dependence of image factors on the respondents age, but the results were not that significant as in the case of respondents' gender.

Since American visitors represent $5.4 \%$ of all non-resident tourists that visited the Czech Republic in 2019 (CSO 2020a) and represent the fifth source country (which is the highest among researched nationalities) for the Czech Republic (CSO 2020b), the regression analysis for American visitors was performed. The results of this analysis are presented in Table 1 and Table 2.

Table 1. Regression Analysis - Intention to Revisit

\begin{tabular}{lcc}
\hline Intention to revisit & Reg. coefficient & P-value \\
\hline Constant & 0.192 & 0.828 \\
\hline Acceptance by the locals & 0.379 & 0.010 \\
\hline Staff quality & 0.295 & 0.022 \\
\hline Price & 0.236 & 0.094
\end{tabular}

Note: $R^{2}=0.173 ; R^{2}$ adj. $=0.139,10 \%$ significance level

Source: Králiková, Ryglová, 2021 
Table 2. Regression Analysis - Recommendation

\begin{tabular}{lcc}
\hline Recommendation & Reg. coefficient & P-value \\
\hline Constant & 0.932 & 0.207 \\
\hline Price & 0.292 & 0.014 \\
\hline Acceptance by the locals & 0.240 & 0.049 \\
\hline Staff quality & 0.225 & 0.036 \\
\hline
\end{tabular}

Note: $R^{2}=0.176 ; R^{2}$ adj. $=0.142,10 \%$ significance level

Source: Králiková, Ryglová, 2021

Overall, there are three image factors that have an impact on intention to revisit as well as recommend the Czech Republic to their acquaintances. Similarly, as for the highest ranking factors by various nationalities, those three factors (acceptance by the locals, staff quality and price) can be, to some extent, altered by the service provider or DMOs. It is therefore very crucial to pay attention to these factors, especially when dealing with visitors' loyalty.

\section{Conclusion}

This paper provides useful insights into the loyalty perception among various nationalities. Based on the results we confirmed that there are differences between the evaluation of loyalty indicators, intention to revisit and recommend the Czech Republic, among American, Russian and Finnish respondents. The biggest difference can be seen in loyalty perception of American respondents, which might be caused by the great geographical distance between the Czech Republic and the US. Furthermore, there are four factors that are significant for the respondents, regardless of their nationality. It is therefore inevitable to pay closer attention to those factors (cultural and natural attractions, safety as well as acceptance by the locals).

Hence, the results can be used by various service providers in central European countries, that are mostly oriented on cultural and city tourism, for their marketing and management plans and campaigns. Service providers can use these results to better target their visitors and offerings to them.

However, there are some limits that should be addressed in the future research. Firstly, the data were obtained before the COVID-19 pandemic. Consequently, the current perception of the Czech Republic might differ from the pre-COVID-19 era. Secondly, the respondents' structure differs among researched nationalities. Therefore, future research should be more balanced regarding the respondents' sample structure. 


\section{Acknowledgements}

This research paper was collaborating with two projects of the Internal Grant Agency of the Faculty of Business and Economics of Mendel University in Brno (PEF_DP_2021015 and PEF_DP_2021011) in 2021.

\section{References}

1. Beerli, A., Martin, J.D. (2004), Factors influencing destination image, Annals of Tourism Research, 31(3), pp. 657-681. https://doi.org/10.1016/j.annals.2004.01.010

2. Bonn, M.A., Joseph, S.M., Dai, M. (2005), International versus domestic visitors: An examination of destination image perceptions, Journal of Travel Research, 43(3), pp. 294-301. https://doi.org/10.1177/0047287504272033

3. CzechTourism (2020). Country Report Russia 2019, https://tourdata.cz/countryreporty/rusko-2019/ (access: 8-6-2021).

4. CzechTourism (2020a). Návštěvnost HUZ - podrobná data (Visitors rate in Main Accommodation Types - Detailed Data), https://tourdata.cz/data/navstevnost-huz-20162020/ (access: 8-6-2021).

5. CzechTourism (2020b). Dopady COVID19 2020 - 2021 (Impacts of COVID 192020 2021), https://tourdata.cz/dopady-covid/dopady-covid19-2020-2021/ (access: 8-62021).

6. Forgas-Coll, S., Palau-Saumell, R., Sánchez-García, J., Callarisa-Fiol, L.J. (2012), Urban destination loyalty drivers and cross-national moderator effects: The case of Barcelona, Tourism Management, 33(6), pp. 1309-1320. https://doi.org/10.1016/j.tourman.2011.12.013

7. Govers, R., Go, F.M., Kumar, K. (2007), Virtual destination image a new measurement approach, Annals of Tourism Research, 34(4), pp. 977-997.

8. Gursoy, D., Chen, J.S., Chi, C.G. (2014), Theoretical examination of destination loyalty formation, International Journal of Contemporary Hospitality Management, Vol. 26, No. 5, pp. 809-827. https://doi.org/10.1108/IJCHM-12-2013-0539

9. Hultman, M., Skarmeas, D., Oghazi, P., Beheshti, H.M. (2015), Achieving tourist loyalty through destination personality, satisfaction, and identification, Journal of Business Research, 68(11), pp. 2227-2231. https://doi.org/10.1016/j.jbusres.2015.06.002

10. Chen C., Tsai, D. (2007), How destination image and evaluative factors affect behavioral intentions? Tourism Management, 28, pp. 1115-1122. https://doi.org/10.1016/j.tourman.2006.07.007

11. Chen, J.S., Gursoy, D. (2001), An investigation of tourists' destination loyalty and preferences, International Journal of Contemporary Hospitality Management, Vol. 13 No. 2, pp. 79-85. https://doi.org/10.1108/09596110110381870

12. Chi, C.G.Q., Qu, H. (2008). Examining the structural relationships of destination image, tourist satisfaction and destination loyalty: An integrated approach, Tourism Management, 29(4), pp. 624-636. https://doi.org/10.1016/j.tourman.2007.06.007

13. Chi, C.G.Q. (2012), An examination of destination loyalty: differences between first time and repeat visitors, Journal of Hospitality and Tourism Research, Vol. 36, No. 1, pp. 3 24. https://doi.org/10.1177/1096348010382235

14. Jackman, M., Lorde, T., Naitram, S., Greenaway, T. (2020), Distance matters: the impact of physical and relative distance on pleasure tourists' length of stay in Barbados, Annals of Tourism Research, 80, 102794. https://doi.org/10.1016/j.annals.2019.102794

15. Králiková, A., Ryglová, K. (2021), Cultural differences as a key determinant of tourist loyalty perception, Acta Academica Karviniensia. In print. ISSN 1212-415X. 
16. Lau, A.L.S., Mckercher, B. (2004), Exploration Versus Acquisition: A Comparison of First-Time and Repeat Visitors, Journal of Travel Research, 42(3), pp. 279-285. https://doi.org/10.1177/0047287503257502

17. Loi, L.T.I., So, A.S.I., Lo, I.S., Fong, L.H.N. (2017), Does the quality of tourist shuttles influence revisit intention through destination image and satisfaction? The case of Macao, Journal of Hospitality \& Tourism Management, 32, pp. 115-123. http://dx.doi.org/10.1016/j.jhtm.2017.06.002

18. Lopes, S.D.F. (2011), Destination image: Origins, developments and implications, Revista de Turismo y Patrimonio Cultural, 9(2), pp. 305-315. http://dx.doi.org/10.25145/j.pasos.2011.09.027

19. Nunkoo, R. (2013), Relationship between Destination Image and Loyalty: Developing Cooperative Branding for Rural Destinations, 3rd international conference on international trade and investment, University of Mauritius. ISSN 16941225.

20. Ryglová, K., Rašovská, I., Šácha, J., Maráková, V. (2018), Building Customer Loyalty in Rural Destinations as a Pre-Condition of Sustainable Competitiveness, Sustainability, 10 (4): 957. https://doi.org/10.3390/su10040957

21. Skogland, I., Siguaw, J.A. (2004), Are Your Satisfied Customers Loyal? Cornell Hotel and Restaurant Administration Quarterly, 45(3), pp. 221-234. https://doi.org/10.1177/0010880404265231

22. Su, H.J., Cheng, K.F., Huang, H.H. (2011), Empirical study of destination loyalty and its antecedent: The perspective of place attachment, The Service Industries Journal, 31(16), pp. 2721-2739. https://doi.org/10.1080/02642069.2010.511188

23. Sun, A., Chi, C.G.Q., Xu, H. (2013), Developing destination loyalty: the case of Hainan Island, China, Annals of Tourism Research, Vol. 43 No. 1, pp. 547-577. https://doi.org/10.1016/j.annals.2013.04.006

24. Swarbrooke, J., Horner, S. (2007), Consumer behavior in tourism, ButterworthHeinemann, Oxford. ISBN 978-0-7506-6735-7

25. Štumpf, P., Vojtko, V., Janeček, P. (2020), Do European tourists intend to revisit the same countries? Effect of satisfaction in European Union destinations, Scandinavian Journal of Hospitality and Tourism, 20(4), pp. 398-417. https://doi.org/10.1080/15022250.2020.1807405

26. Usakli, A., Baloglu, S. (2011), Brand personality of tourist destinations: an application of self-congruity theory, Tourism Management, 32, pp. 114-137. https://doi.org/10.1016/j.tourman.2010.06.006

27. Viet, B.N. (2019), The influence of destination image components on tourist satisfaction and loyalty: A case study in Côn Đảo Islands, Vietnam, African Journal of Hospitality, Tourism and Leisure, Vol. 8 (4). ISSN: 2223-814X

28. Wu, Chih-Wen. (2016), Destination loyalty modeling of the global tourism. Journal of Business Research, 69(6), pp. 2213-2219. DOI 10.1016/j.jbusres.2015.12.032.

29. Zhang, H., Fu, X., Cai, L.A., Lu, L. (2014), Destination image and tourist loyalty: A $\begin{array}{llll}\text { meta-analysis, } \quad \text { Tourism } & \text { Management, } 13-223 .\end{array}$ https://doi.org/10.1016/j.jbusres.2015.12.032

30. Zhang, X. (2013), The Image of Wuhan as a Tourist Destination, Haaga-Helia University of Applied Sciences, Finland, https://www.theseus.fi/handle/10024/133917 (access: 8-6-2021). 